\title{
Innovation of impairment loss allowance model of Indonesian financial accounting standards 71
}

Innovative impairment loss allowance model

\author{
Sugiarto Sugiarto \\ Department of Management, Universitas Prasetiya Mulya, \\ Jakarta Selatan, Indonesia, and \\ Suroso Suroso \\ Bank Jasa Jakarta, Jakarta, Indonesia
}

Received 24 November 2019

Revised 23 January 2020

Accepted 26 January 2020

\begin{abstract}
Purpose - This study aims to develop a high-quality impairment loss allowance model in conformity with Indonesian Financial Accounting Standards 71 (PSAK 71) that has significant contribution to national interests and the banking industry.

Design/methodology/approach - The determination of the impairment loss allowance model is settled through 7 stages, using integration of some statistical methods such as Markov chain, exponential smoothing, time series analysis of behavioral inherent trends of probability of default, tail conditional expectation and Monte Carlo simulation.

Findings - The model which is developed by the authors is proven to be a high-quality and reliable model. By using the model, it can be shown that the implementation of the expected credit losses model on Indonesian Financial Accounting Standards 71 is more prudent than the implementation of the incurred loss model on Indonesian Financial Accounting Standards 55.

Research limitations/implications - Determination of defaults was based on days past due, and the analysis in this study did not touch the aspects of hedge accounting in general.

Practical implications - This developed model will contribute significantly to national interests as a source of reference for other banks operating in Indonesia in calculating impairment loss allowance (CKPN) and can be used by the Financial Services Authority of Indonesia (OJK) as a guideline in assessing the formation of impairment loss allowance for banks operating in Indonesia.

Originality/value - As so far there is not yet an available standardized model for calculating impairment loss allowance on the basis of Indonesian Financial Accounting Standards 71, the model developed by the authors will be a new breakthrough in Indonesia.
\end{abstract}

Keywords PSAK 71, Impairment loss allowance, CKPN, Forward looking

Paper type Research paper

\section{Introduction}

Enactment of the Indonesian Financial Accounting Standards 71 (Pernyataan Standar Akuntansi Keuangan 71, PSAK 71), which is an adoption of International Financial Reporting Standards 9 (IFRS 9), will be effective in early 2020 in place of PSAK 55, which was an adoption of International Accounting Standards 39 (IAS 39) (Surat Edaran OJK S-78/ PB.11/2017).

IFRS 9 replaces IAS 39 in response to criticisms that IAS 39 is too complex, inconsistent with the way entities manage their businesses and risks and defers the recognition of credit losses on loans and receivables until too late in the credit cycle (PWC, 2017; PWC, 2017a;

(C) Sugiarto Sugiarto and Suroso Suroso. Published in Journal of Asian Business and Economic Studies. Published by Emerald Publishing Limited. This article is published under the Creative Commons Attribution (CCBY 4.0) licence. Anyone may reproduce, distribute, translate and create derivative works of this article (for both commercial and non-commercial purposes), subject to full attribution to the original publication and authors. The full terms of this licence may be seen at http://creativecommons. org/licences/by/4.0/legalcode

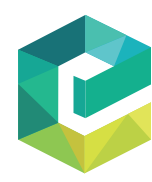

Journal of Asian Business and Economic Studie Vol. 27 No. 3,2020 pp. $267-283$ 
JABES 27,3

Deloitte, 2018). In line with the reason for the replacement of IAS 39 with IFRS 9, the replacement of PSAK 55 with PSAK 71 is based on the following three main considerations: the provisions applied in PSAK 55 were considered complex and based on rule in determining the classification of financial instruments, the determination of impairments in PSAK 55 was considered late and did not reflect facts when economic conditions were in crisis and the provisions applied in PSAK 55 were not flexible and did not reflect risk management strategies (KPMG, 2018; Walton 2004; Lim et al., 2013).

In Pernyataan Standar Akuntansi Keuangan (PSAK) 55, the concept of impairment used an incurred loss model (PSAK 55 par. 59) wherein the recognition of credit loss allowances was triggered by loss events subsequent to origination (PWC, 2017). For impairment information, historical data (past due information) were used. Financial assets are impaired in value if and only if there were objective evidences of impairment as a result of one or more events that occurred after the initial recognition of the asset and the adverse event impacted on estimating future cash flows from financial assets or groups financial assets that could be estimated (Walton 2004; Lim et al., 2013).

In PSAK 71 or the Indonesian Financial Accounting Standards 71, impairment in financial instruments is no longer carried out using an incurred loss model such as PSAK 55 but based on expected credit loss (ECL). As the new IFRS 9 impairment model requires impairment allowances for all exposures from the time a loan is originated, based on the deterioration of credit risk since initial recognition, the assessment of credit risk and the estimation of ECL in PSAK 71 must reflect an unbiased evaluation of a range of possible outcomes and their probabilities of occurrence including discounting for the time value of money, reasonable and supportable information that is available without undue cost or effort at the reporting date about past events and current conditions and forecasts of future economic conditions (Duh et al., 2012; Lim et al., 2013; Walton, 2004, PWC, 2017, PWC, 2017a). If the credit risk has not increased significantly (bucket 1), IFRS 9 requires allowances based on 12 months' expected losses. If the credit risk has increased significantly (bucket 2) and if the loan is "credit impaired" (bucket 3), the standard requires allowances based on lifetime expected losses (EY, 2018; EY 2019). Determining whether loss allowances are measured using lifetime ECLs or 12-month ECL depended on significant changes in financial instruments' credit risk since initial recognition of the nominal ECLs (IFRS Foundation, 2014; Beerbaum 2015). In determining whether a financial instrument's credit risk had increased significantly since initial recognition, it was required that at each reporting date, management compared the risk of default on the financial instrument since initial recognition at the reporting date (risk of default at reporting date) and considered the available related information (reasonable and supportable information) (IFRS 9 par. 5.5.9). For impairment information, historical data (past due information) and future macroeconomic predictions (forward-looking macroeconomic information) were used (PWC, 2017).

In general, there are three main differences between PSAK 55 and PSAK 71 related to the classification and measurement of financial assets and financial liabilities and decrease in the value of ECLs and general hedge accounting. Regarding the decline in the value of ECLs, in PSAK 71, the provision of expected loss models is based on ECLs. Collective impairment in PSAK 71 uses a 12-month ECL for bucket 1 (credit with good quality, days past due (DPD) $\leq$ 30 days) and lifetime ECLs for bucket 2 (credit with poor quality, 31 days $\leq$ DPD $\leq 90$ days) and bucket 3 (credit with deteriorating quality, DPD $\geq 91$ days). The transition to IFRS 9 generally resulted in an increase in impairment allowances (EY, 2018). For the majority of banks analysed, the transition to IFRS 9 generally results in an increase in allowances, ranging from a few millions to EUR4 billion (EY, 2018). As a result, banks must set aside a portion of their capital to foster more reserves (Beerbaum 2015). Although it is more unfavorable for banks to record ECLs that become a considerable "burden" in their financial 
statements, it is to be noted that IFRS 9 will contribute in providing a more objective and prospective view of banks (Johannes et al., 2018).

In connection with the planned implementation of PSAK 71, banks operating in Indonesia are required by the Financial Services Authority of Indonesia (OJK) to conduct a gap analysis of changes in the size of impairment loss allowance (Cadangan Kerugian Penurunan Nilai, CKPN), compared to when banks base their CKPN on PSAK 55. To do a gap analysis, it is needed a model that is able to calculate the amount of CKPN comprehensively.

So far IFRS 9 implementation in various countries shows no standard model. There were numerous models that were used to form the probability of default models as a major component of ECL. The probability of default was evaluated using diverse provisioning approaches, varying between banks and countries (PWC, 2017; PWC, 2017a), such as migration risk, "simplified approach" based on the provision matrix (Deloitte, 2018) and the Black-Scholes model for European call options (Dar et al., 2019). Although those models used have been stated 'simple' by the researcher, the models used so far were still considered complicated by the laity. Likewise the conditions faced in Indonesia, so far there is not yet an available standardized model for banks operating in Indonesia for calculating CKPN on the basis of PSAK 71. OJK has not proposed a standardized model either, with the consideration that PSAK 71 applies principle-based model and not rule based model. Thus, every bank operating in Indonesia is given the freedom to develop a CKPN projection model for their respective banks as long as the model they developed follows the rules set forth in PSAK 71 and their model reliability can be justified.

In connection with the planned implementation of PSAK 71, the question is whether it is possible to develop a high-quality and highly reliable model that is not only able to produce the amount of impairment loss allowance comprehensively and that emphasizes parsimonious aspect that is scientifically proven but also fulfills provisions set by the Financial Services Authority of Indonesia. This study aims to develop an impairment loss allowance model that meets the requirements of PSAK 71, which becomes the novelty of this research. To become a high quality model, it should have ability to represent what happens in reality and also have a high predictive ability at tolerable error rates (Ksenofontov et al., 2016; Sugiarto et al., 2019). To prove the reliability of the model, back tests were carried out using historical Probability of default (PD) data. If the model developed by authors proves to be a high quality and reliable model, this developed model will contribute significantly to national interests due to which it can be a source of reference for other banks operating in Indonesia in calculating CKPN and can also be used by OJK as a guideline in assessing the formation of reserves carried out by banks operating in Indonesia.

To show the reliability of the model developed by the authors, study was conducted using Bank Jasa Jakarta (BJJ), a private bank operating in Indonesia, as the bank that tests this model. BJJ was chosen for testing this model due to its excellence and consistency in performance. Throughout its history, BJJ had succeeded in maintaining its position as a healthy and solid bank and in consistently implementing prudent policies aimed at maintaining credit quality, maintaining strong capital and managing a healthy liquidity position. For the achievement of good performance so far, BJJ had received many awards from several banking institutions.

\section{Literature review}

\subsection{Expected credit losses}

ECLs represent possible outcomes weighed by the probability of their occurrence (PWC, 2019). Under the "expected credit loss" model, an entity calculates the allowance for credit losses by considering on a discounted basis the cash shortfalls it would incur in various
Innovative impairment loss allowance model 
JABES 27,3 default scenarios for prescribed future periods and then multiplying the shortfalls by the probability of each scenario occurring. The allowance is the sum of these probabilityweighted outcomes. Because every loan and receivable carries with it some risk of default, every such asset has an expected loss attached to it - from the moment of its origination or acquisition. In all cases, the allowance and any changes to it are recognized by recognizing impairment gains and losses in profit and loss. ECLs are calculated as follows: (1) identifying scenarios in which a loan or receivable defaults; (2) estimating the cash shortfall that would be incurred in each scenario if a default were to happen; (3) multiplying that loss by the probability of the default happening and (4) summing the results of all such possible default events (PWC, 2017; PWC, 2017a; EY, 2018). IFRS 9 emphasizes that estimating ECLs may not necessarily need to be a complex process and that an entity need not identify every possible scenario. IFRS 9 also permits the use of models for estimating expected losses that do not require explicit scenario and probability analysis. In some cases, relatively simple modeling may be sufficient without the need for a large number of detailed simulations or scenarios. In others, entities will need to determine how many more scenarios are required (PWC, 2017, EY, 2018).

\subsection{Impairment loss allowance}

ECLs are used as the basis for calculating the impairment allowance and the risk adjusted interest (PWC, 2017; EY 2018; EY, 2019). According to Basel Committee on Banking Supervision (2015), in carrying out calculations of collective impairments, the modeling system of the impairment collective calculation uses the following approach: probability of default $(\mathrm{PD}) \times$ loss given default $(\mathrm{LGD}) \times$ exposure at default $(\mathrm{EAD})$. $\mathrm{ECL}$ is the discounted product of PD, EAD and LGD (PWC, 2017). PD is an estimate of the likelihood of a default over a given time horizon. LGD is the amount that would be lost in the event of a default. EAD is the expected outstanding balance of the receivable at the point of default.

Data of probability of default are obtained from forward-looking probability of default due to credit risk related to 3 buckets on PSAK 71. By using the days past due (DPD) criteria on PSAK 71, 3 buckets were used in forward-looking probability of default (International Accounting Standard Board, 2014) as follows: bucket 1 for credit with good quality (DPD $\leq 30$ days); bucket 2 for credit with poor quality (31 days $\leq \mathrm{DPD} \leq 90$ days) and bucket 3 for credit with deteriorating quality (DPD $\geq 91$ days). LGD data use a combined calculation of non-performing loans based on expected recoveries, collateral shortfall and loss on disposal. The starting point of observation uses "delete book data". For LGD data, the results of observations made during the last ten years have been used. Present value recovery uses contractual rate. $L G D=1$-recovery rate. $L G D$ data were calculated using provisions from the Basel Committee on Banking Supervision (2015). EAD data are obtained on the basis of calculations based on gross amount and net amount, using provisions from the Basel Committee on Banking Supervision (2015). The estimation of ECL takes into account the time value of money.

The recognition and measurement of impairment is intended to be more forward looking than under IAS 39, and the resulting impairment charge will tend to be more volatile (Basel Committee on Banking Supervision, 2015; Duh et al., 2012; Lim et al., 2013; Walton, 2004). Impairment collective calculation based on IFRS 9 will contribute in providing a more objective and prospective view of financial industry (Johannes et al., 2018).

\subsection{Positive accounting theory and normative accounting theory}

Positive accounting theory is a statement that accounting theory attempts to explain and predict accounting practices (Watts and Zimmerman, 1990; Watts and Zimmerman, 1978). As one of the most considered works in accounting, positive accounting theory had contributed 
considerable findings on empirical regularities and explanations behind those regularities, despite numerous criticisms regarding this theory. The single most important task facing positive accounting researchers is improving the linkage between the theory and empirical tests (Watts and Zimmerman, 1990).

Normative accounting theories focused on what "should be" rather than what "it is". This lead to normative accounting researchers getting more concerned with policy recommendations rather than analyzing and explaining the currently accepted and implemented practice (Ingenbleek and van der Lans 2013; Kabir, 2005).

In this research, data analysis and explanation will be based on empirical data support and not based on normative argumentation. Thus, the researcher will base the discussion on a positive basis rather than on a normative basis as long as empirical data support and can be justified. The empirical test can no longer assume accounting choice is made for either efficiency or opportunistic reason. Both must be incorporated into the test to further refine the linkage between the theory and test, by identifying empirical data support. The positive accounting literature has yielded empirical regularities and exploitations for these regularities, and it is clear there are many research opportunities available beyond those currently exploited (Watts and Zimmerman, 1990).

\section{Research methods}

This study aims to develop a high-quality impairment loss allowance model in conformity with Indonesian Financial Accounting Standards 71 that has significant contribution to national interests and the banking industry through various filters at each stage in the model formation. Impairment loss allowance model of Indonesian Financial Accounting Standards 71 developed by the authors is shown in Figure 1 as shown below:

In forming forward-looking PD models and impairment loss allowance model of Indonesian Financial Accounting Standards 71, the authors use positive accounting

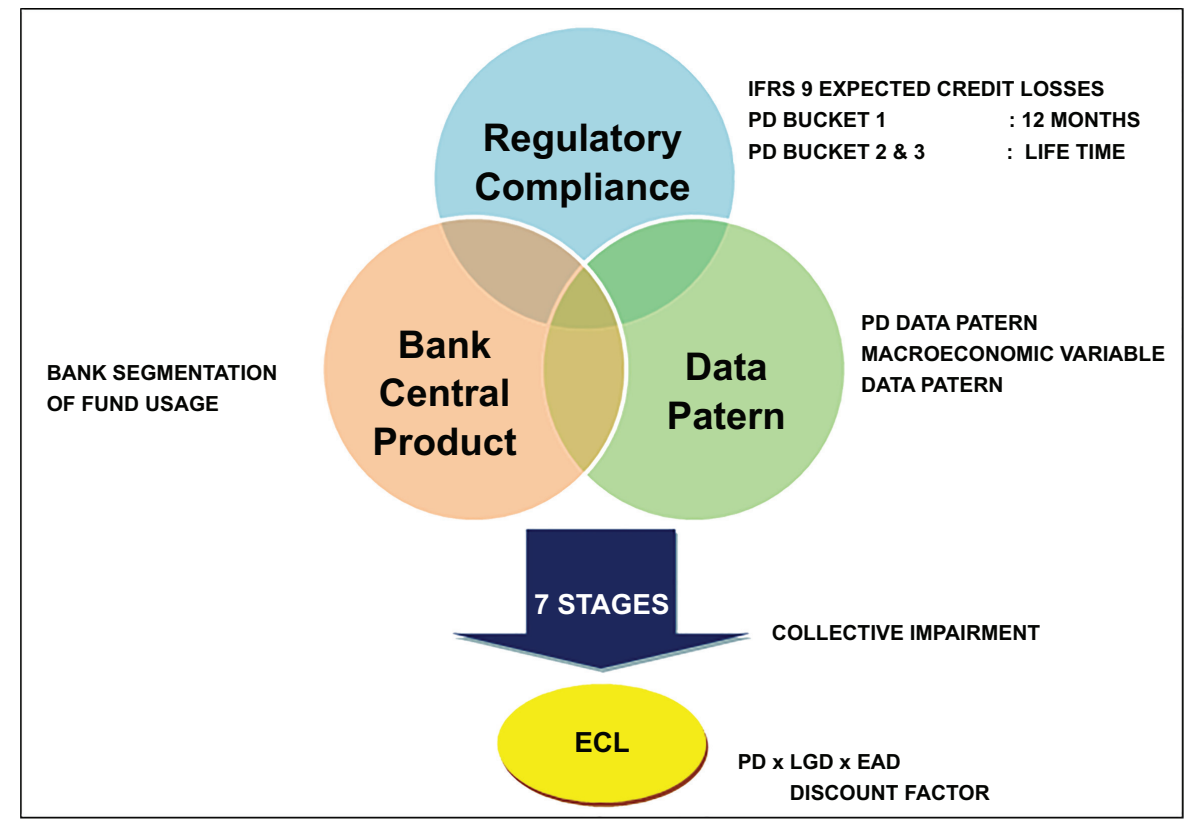

Innovative impairment loss allowance model
Figure 1. Impairment loss allowance model of Indonesian Financial

Accounting Standards 71 
JABES 27,3 theory. To test the reliability of the model, the PD data from Bank Jasa Jakarta (BJJ) of the last three years (2015-2017) were based on the following three types of funds usage: working capital, investment and consumption. The PD data generated from the migration analysis of 7662 BJJ's credit data for the past six years (2012-2017) used the Markov chain concept.

PD data of Bank Jasa Jakarta of the last three years (PD data 2015-2017) were generated from the Bank Jasa Jakarta credit data for 2012-2017 by migration mechanism based on the Markov chain concept as follows: for every years, there were 4 PD data due to $\mathrm{PD}$ data used being quarterly PD data. 1st quarter PD data is March PD data, 2nd quarter PD data is June PD data, 3rd quarter PD data is September PD data and 4th quarter PD data is December PD data. PD data for March 2015, which in this case is PD Data for 1st quarter of 2015, were generated from three times migration from credit data in March 2012, March 2013, March 2014 and March 2015. The same method was used to generate PD data in quarters 2, 3 and 4 each year. Thus, even though the PD data used in the analysis were PD data of the last 3 years, namely 2015, 2016 and 2017, credit data from the past 6 years (2012-2017) were needed to form those PD data of 2015, 2016 and 2017.

\subsection{Impairment loss allowance model}

The determination of the collective impairment modeling in this research is settled through 7 stages:

(1) Stage 1: Generate PD data from Bank Jasa Jakarta for the last 3 years (PD data 20152017) and determine inherent behavioral trend PD patterns

(2) Stage 2: Calculate projection PD per bucket per segment

(3) Stage 3: Determine macroeconomic variables trend patterns

(4) Stage 4: Calculate macroeconomic variables projection values

(5) Stage 5: Determine projection PD on the basis of macroeconomic variables values

(6) Stage 6: Conduct the assumption test

(7) Stage 7: Determine the value of ECL estimation

At stage 1, PD Modeling is based on the arrears approach. These models based their prediction on the assumption that the future is a continuation of the past (Rombe, 2018; Chambers et al., 1971). Forward-looking probability of default modeling is all about predicting the future of PD as accurately as possible, having all the information available including historical data and knowledge of any future events that might impact the forecasts. Analysis of time series data required identification of the underlying behavior of the series (Rombe, 2018; Chambers et al., 1971). At stage 1, 11 trend patterns were tried out as follows: linear, quadratic, cubic, logarithmic, inverse, compound, power, S, growth, exponential and logistic. To reduce randomness trend, exponential smoothing was used for PD data from the results of migration analysis for the last three years.

At stage 2, for PD bucket 1, projections for one year were carried out based on the determination of the pattern of inherent behavioral trends in PD. For PD bucket 2 and bucket 3 , $\mathrm{PD}$ projections were performed using the concepts of tail value at risk (TVaR) and Monte Carlo iteration.

Macroeconomic variables in this research were determined on the basis of economics theory or empirical fact (Ksenofontov et al., 2016). According to Pesaran (2005), asset value changes of banks in a credit portfolio are linked to a dynamic global macroeconomic 
variable. The macroeconomic variables used were as follows: inflation, GDP, exchange rate, BI rate and unemployment rate. At stage 3, 11 trend patterns were tried out as follows: linear, quadratic, cubic, logarithmic, inverse, compound, power, S, growth, exponential and logistic.

At stage 4, as IFRS 9, PSAK 71 requires multiple forward-looking macroeconomic and workout scenarios for the estimation of ECLs (PWC, 2017a, EY, 2018; EY 2019). The projection of macro variable values was based on the best data pattern.

At stage 5, confirmation of the reliability of projection results was tested from the small errors generated by the PD projection difference from the real $\mathrm{PD}$. The projection $\mathrm{PD}$ value must meet the criteria $0 \leq \mathrm{PD} \leq 1$.

At stage 6 , the model used fulfilling the classical assumption of ordinary least square, $p$-value of independent variable $\leq 0,05, R$-square model $\geq 0,64$.

At stage 7 , the weighted averages of PD projection were used. Weighted average performed on $\mathrm{PD}$ projection results from the integration of internal pattern projection and external pattern using formula $\overline{\mathrm{PD}}=w_{1} \widehat{\mathrm{PD}}_{\alpha=0.1}+w_{2} \widehat{\mathrm{PD}}_{\alpha=0.5}+w_{3} \widehat{\mathrm{PD}}_{\alpha=0.9}$. LGD data use a combined calculation of non-performing loans based on expected recoveries, collateral shortfall and loss on disposal. The starting point of observation uses "delete book data". For LGD data, the results of observations made during the last 10 years have been used. Present value recovery uses contractual rate. $\mathrm{LGD}=1$-recovery rate. EAD data are obtained on the basis of calculations based on gross amount and net amount. The estimation of ECL takes into account the time value of money.

\section{Result}

From PD modeling, 45 equations that have been tested for reliability of the model were obtained. The reliability tests of PD modeling were done by the test of data pattern and by considering the effects of macroeconomic variables. The results of forward-looking PD testing have gone through double-checking the ability of the explanatory model to provide PD projection as shown in Table I. Although 11 candidate patterns of data were tried, the search results of the data pattern showed that the PD data patterns of Bank Jasa Jakarta displayed three main patterns, namely linear, quadratic and cubic, as shown in Table I.

The findings state that all prediction equations of buckets 1,2 and 3 with a period of $<12$ months show model reliability above 80 percent. All prediction equations are in high reliability so that the forward-looking results generated from these equations can be expected to be reliable and representative.

The findings in Table II state that all prediction equations of the macroeconomics equation of buckets 1,2 and 3 with a period of $<12$ months also show model reliability above 80 percent. All prediction equations are in high reliability so that the forward-looking results generated from these equations can be expected to be reliable and representative.

The findings in Table III also state that all prediction equations of macroeconomic equations including lifetime buckets 2 and 3, using TVaR, show model reliability above 80 percent. All prediction equations are in high reliability so that the forward-looking results generated from these equations can be expected to be reliable and representative. To demonstrate the reliability of the model, one example of the back test result was given on the working capital segment with smoothing coefficient of 0.1 in the bucket 2 as shown in Table IV.

The equation formed was $\mathrm{PD}=-0.12+5.38 E-08 \mathrm{GDP}-0.32$ Inflation. In this equation, macroeconomic variable GDP has a negative significant effect on PD. An increase in GDP will decrease PD and conversely a decrease in GDP will increase PD. Macroeconomic variable inflation has a negative significant effect on PD. Based on positive accounting theory, empirical data state that when there was an increase in inflation, the PD value declines, with the argument that when 


\begin{tabular}{|c|c|c|c|c|c|}
\hline $\begin{array}{l}\text { JABES } \\
27,3\end{array}$ & Bucket & Segment & $\begin{array}{c}\text { Coefficient } \\
\text { of } \\
\text { smoothing }\end{array}$ & Equation & $\begin{array}{l}\text { Model } \\
\text { reliability }\end{array}$ \\
\hline \multirow{23}{*}{274} & 1 & $\begin{array}{l}\text { Working } \\
\text { capital }\end{array}$ & 0.1 & $\mathrm{PD}=0.0+0.0000243 T$ & 0.913 \\
\hline & 1 & $\begin{array}{l}\text { Working } \\
\text { capital }\end{array}$ & 0.5 & $\mathrm{PD}=0.0+0.0000196 T+0.000002608 T^{2}$ & 0.896 \\
\hline & 1 & $\begin{array}{l}\text { Working } \\
\text { capital }\end{array}$ & 0.9 & $\mathrm{PD}=0.0+0.00005038 T+0.0000003395 T^{2}$ & 0.855 \\
\hline & 1 & Investment & 0.1 & $\mathrm{PD}=0.00006963+0.00002557 T$ & 0.922 \\
\hline & 1 & Investment & 0.5 & $\mathrm{PD}=0.00004552+0.00004445 T+0.0000009776 T^{2}$ & 0.918 \\
\hline & 1 & Investment & 0.9 & $\mathrm{PD}=-0.000006515+0.00007824 T-0.000001415 T^{2}$ & 0.843 \\
\hline & 1 & Consumption & 0.1 & $\mathrm{PD}=0.00007045-0.00000432 T+0.000001256 T^{2}$ & 0.989 \\
\hline & 1 & Consumption & 0.5 & $\mathrm{PD}=0.00002948+0.0000135 T+0.000001174 T^{2}$ & 0.943 \\
\hline & 1 & Consumption & 0.9 & $\mathrm{PD}=-0.0000007975+0.00003075 T+0.00000001191 T^{2}$ & 0.911 \\
\hline & 2 & $\begin{array}{l}\text { Working } \\
\text { capital }\end{array}$ & 0.1 & $\mathrm{PD}=0.003+0.005 T+0.000009962 T^{2}$ & 0.995 \\
\hline & 2 & $\begin{array}{l}\text { Working } \\
\text { capital }\end{array}$ & 0.5 & $\mathrm{PD}=0.008+0.013 T+0 T^{2}$ & 0.903 \\
\hline & 2 & $\begin{array}{l}\text { Working } \\
\text { capital }\end{array}$ & 0.9 & $\mathrm{PD}=0.02+0.011 T+0 T^{2}$ & 0.854 \\
\hline & 2 & Investment & 0.1 & $\mathrm{PD}=0.03+0.002 T+0.00003036 T^{2}-0.00000416 T^{3}$ & 0.986 \\
\hline & 2 & Investment & 0.5 & $\mathrm{PD}=0.025+0.008 T+0 T^{2}$ & 0.841 \\
\hline & 2 & Investment & 0.9 & $\mathrm{PD}=0.007 T$ & 0.860 \\
\hline & 2 & Consumption & 0.1 & $\mathrm{PD}=0.003+0.002 T$ & 0.917 \\
\hline & 2 & Consumption & 0.5 & $\mathrm{PD}=0+0.003 T+0.0000718 T^{2}$ & 0.934 \\
\hline & 2 & Consumption & 0.9 & $\mathrm{PD}=0+0.004 T$ & 0.897 \\
\hline & 3 & $\begin{array}{l}\text { Working } \\
\text { capital }\end{array}$ & 0.1 & $\mathrm{PD}=0.824+0.005 T+0.00006056 T^{2}$ & 0.986 \\
\hline & 3 & $\begin{array}{l}\text { Working } \\
\text { capital }\end{array}$ & 0.5 & $\mathrm{PD}=0.825+0.003 T+0.003 T^{2}+0 T^{3}$ & 0.991 \\
\hline & 3 & $\begin{array}{l}\text { Working } \\
\text { capital }\end{array}$ & 0.9 & $\mathrm{PD}=0.816+0.013 T+0.001 T^{2}+0 T^{3}$ & 0.971 \\
\hline & 3 & Investment & 0.1 & $\mathrm{PD}=0.891+0.004 T+0 T^{2}$ & 0.985 \\
\hline & 3 & Investment & 0.5 & $\mathrm{PD}=0.942-0.015 T$ & 0.872 \\
\hline & 3 & Investment & 0.9 & $\mathrm{PD}=0.922-0.009 T+0 T^{2}$ & 0.856 \\
\hline liction equations & 3 & Consumption & 0.1 & $\mathrm{PD}=0.665-0.009 T+0.001 T^{2}$ & 0.986 \\
\hline buckets 1,2 and 3 with & 3 & Consumption & 0.5 & $\mathrm{PD}=0.591+0.014 T$ & 0.877 \\
\hline a period of $<12$ months & 3 & Consumption & 0.9 & $\mathrm{PD}=0.581+0.016 T$ & 0.807 \\
\hline
\end{tabular}

there is inflation, the debtors respond by spending savings by prioritizing the ability to maintain the repayment power of their debts. The magnitude of the reliability of the model was shown by the $R$ square value of 0.969 . Errors were obtained from differences in projection PD result related to real PD. Display of errors in Table IV showed that the resulting errors of the model were very small and thus supported high model reliability. Figure 2 shows the PD projection patterns and real PD throughout the observation time. The data patterns indicated that the projection results were close to the real data which results in small errors. Thus, the model used has good reliability in projecting real conditions. From the scatter plot of errors in Figure 3, it was shown that there was no pattern in the errors during the observation time. This condition states fulfillment of the assumptions of the model used.

Table $\mathrm{V}$ show the projection PD formed using three smoothing coefficients. The PD projection data in Table $\mathrm{V}$ will be used to produce the forward-looking probability of default 


\begin{tabular}{|c|c|c|c|c|c|c|c|}
\hline Bucket & Segment & $\begin{array}{l}\text { Coefficient } \\
\text { of } \\
\text { smoothing }\end{array}$ & Equation & $\begin{array}{l}\text { Model } \\
\text { reliability }\end{array}$ & $\begin{array}{l}\text { Projection } \\
\text { December } \\
2017\end{array}$ & $\begin{array}{l}\text { Projection } \\
\text { December } \\
2018\end{array}$ & $\begin{array}{l}\text { Innovative } \\
\text { impairment } \\
\text { loss allowance }\end{array}$ \\
\hline 1 & $\begin{array}{l}\text { Working } \\
\text { capital }\end{array}$ & 0.1 & $\begin{array}{l}\mathrm{PD}=3.49 \mathrm{E}-08 \\
\text { Exchange Rate }\end{array}$ & 0.950 & 0.00047296 & 0.00048513 & model \\
\hline 1 & $\begin{array}{l}\text { Working } \\
\text { capital }\end{array}$ & 0.5 & $\begin{array}{l}\mathrm{PD}=0.00 \\
\mathrm{E}+00+4.80 \mathrm{E}-10 \\
\mathrm{GDP}\end{array}$ & 0.899 & 0.00167619 & 0.00185654 & 275 \\
\hline 1 & $\begin{array}{l}\text { Working } \\
\text { capital }\end{array}$ & 0.9 & $\mathrm{PD}=2.24 \mathrm{E}-10 \mathrm{GDP}$ & 0.959 & 0.00078155 & 0.00086564 & \\
\hline 1 & Investment & 0.1 & $\begin{array}{l}\mathrm{PD}=0.00 \\
\mathrm{E}+00+3.48 \mathrm{E}-10 \\
\mathrm{GDP}\end{array}$ & 0.955 & 0.00121543 & 0.00134621 & \\
\hline 1 & Investment & 0.5 & $\begin{array}{l}\mathrm{PD}=-2.00 \mathrm{E}- \\
03+8.31 \mathrm{E}-10 \mathrm{GDP}\end{array}$ & 0.953 & 0.00090104 & 0.00121319 & \\
\hline 1 & Investment & 0.9 & $\begin{array}{l}\mathrm{PD}=1.00 \mathrm{E}-03-1.70 \\
\mathrm{E}-02 \text { BI Rate }\end{array}$ & 0.906 & 0.00027750 & 0.00042845 & \\
\hline 1 & Consumption & 0.1 & $\begin{array}{l}\mathrm{PD}=0+2.34 \mathrm{E}-10 \\
\mathrm{GDP}+0.001 \text { Inflation }\end{array}$ & 0.966 & 0.00085430 & 0.00097617 & \\
\hline 1 & Consumption & 0.5 & $\begin{array}{l}\mathrm{PD}=-1.000 \mathrm{E}- \\
03+4.57 \mathrm{E}-10 \mathrm{GDP}\end{array}$ & 0.959 & 0.00059660 & 0.00076840 & \\
\hline 1 & Consumption & 0.9 & $\begin{array}{l}\mathrm{PD}=-1.00 \mathrm{E}- \\
03+4.18 \mathrm{E}-10 \mathrm{GDP}\end{array}$ & 0.936 & 0.00046047 & 0.00061761 & \\
\hline 2 & $\begin{array}{l}\text { Working } \\
\text { capital }\end{array}$ & 0.1 & $\begin{array}{l}\mathrm{PD}=-0.187+7.07 \\
\mathrm{E}-08 \mathrm{GDP}\end{array}$ & 0.980 & 0.05971617 & 0.08626238 & \\
\hline 2 & $\begin{array}{l}\text { Working } \\
\text { capital }\end{array}$ & 0.5 & $\begin{array}{l}\mathrm{PD}=-0.463+1.72 \\
\mathrm{E}-07 \text { GDP }\end{array}$ & 0.897 & 0.13668645 & 0.20121161 & \\
\hline 2 & $\begin{array}{l}\text { Working } \\
\text { capital }\end{array}$ & 0.9 & $\begin{array}{l}\mathrm{PD}=-0.376+1.45 \\
\mathrm{E}-07 \mathrm{GDP}\end{array}$ & 0.902 & 0.13153440 & 0.18614417 & \\
\hline 2 & Investment & 0.1 & $\begin{array}{l}\mathrm{PD}=0.068-0.433 \mathrm{BI} \\
\text { Rate }\end{array}$ & 0.950 & 0.04959750 & 0.05344221 & \\
\hline 2 & Investment & 0.5 & $\begin{array}{l}\mathrm{PD}=-0.26+1.02 \mathrm{E}- \\
07 \mathrm{GDP}\end{array}$ & 0.865 & 0.09639108 & 0.13473810 & \\
\hline 2 & Investment & 0.9 & $\begin{array}{l}\mathrm{PD}=0.129+5.97 \mathrm{E}- \\
08 \mathrm{GDP}\end{array}$ & 0.889 & 0.07931949 & 0.10173428 & \\
\hline 2 & Consumption & 0.1 & $\begin{array}{l}\mathrm{PD}=-0.073+2.79 \\
\mathrm{E}-08 \mathrm{GDP}\end{array}$ & 0.962 & 0.02424834 & 0.03471208 & \\
\hline 2 & Consumption & 0.5 & $\begin{array}{l}\mathrm{PD}=-0.154+5.69 \\
\mathrm{E}-08 \mathrm{GDP}\end{array}$ & 0.954 & 0.04465050 & 0.06602493 & \\
\hline 2 & Consumption & 0.9 & $\begin{array}{l}\mathrm{PD}=0.1-1.236 \mathrm{BI} \\
\text { Rate }\end{array}$ & 0.956 & 0.04747000 & 0.05844475 & \\
\hline 3 & $\begin{array}{l}\text { Working } \\
\text { capital }\end{array}$ & 0.1 & $\begin{array}{l}\mathrm{PD}=0.6+8.24 \mathrm{E}-08 \\
\mathrm{GDP}\end{array}$ & 0.976 & 0.88773082 & 0.91869012 & \\
\hline 3 & $\begin{array}{l}\text { Working } \\
\text { capital }\end{array}$ & 0.5 & $\begin{array}{l}\mathrm{PD}=-1.457+6.73 \\
\mathrm{E}-07 \mathrm{GDP}+6.212 \\
\text { Inflation }\end{array}$ & 0.953 & 0.92628570 & 0.91762534 & \\
\hline 3 & $\begin{array}{l}\text { Working } \\
\text { capital }\end{array}$ & 0.9 & $\begin{array}{l}\mathrm{PD}=-0.24+3.71 \mathrm{E}- \\
07 \mathrm{GDP}\end{array}$ & 0.857 & 0.89153212 & 0.76790192 & \\
\hline 3 & Investment & 0.1 & $\begin{array}{l}\mathrm{PD}=0.0000661 \\
\text { Exchange Rate }\end{array}$ & 0.998 & 0.89552280 & 0.91857187 & \\
\hline 3 & Investment & 0.5 & $\begin{array}{l}\mathrm{PD}=1.48 \mathrm{E}+00- \\
2.04 \mathrm{E}-07 \mathrm{GDP}\end{array}$ & 0.928 & 0.76896315 & 0.69245689 & Table II. \\
\hline 3 & Investment & 0.9 & $\begin{array}{l}\mathrm{PD}=0.645+3.36 \\
\mathrm{E}+00 \mathrm{BI} \text { Rate }\end{array}$ & 0.859 & 0.78767250 & (continued) & $\begin{array}{r}\text { The macroeconomics } \\
\text { equation of buckets } 1,2 \\
\text { and } 3 \text { with a period } \\
\text { of }<12 \text { months }\end{array}$ \\
\hline
\end{tabular}




\begin{tabular}{|c|c|c|c|c|c|c|c|}
\hline $\begin{array}{l}\text { JABES } \\
27,3\end{array}$ & Bucket & Segment & $\begin{array}{l}\text { Coefficient } \\
\text { of } \\
\text { smoothing }\end{array}$ & Equation & $\begin{array}{l}\text { Model } \\
\text { reliability }\end{array}$ & $\begin{array}{l}\text { Projection } \\
\text { December } \\
2017\end{array}$ & $\begin{array}{c}\text { Projection } \\
\text { December } \\
2018\end{array}$ \\
\hline & 3 & Consumption & 0.1 & $\begin{array}{l}\mathrm{PD}=0.272+1.11 \mathrm{E}- \\
07 \mathrm{GDP}+9.83 \mathrm{E}-01 \\
\text { Inflation }\end{array}$ & 0.943 & 0.69319848 & 0.76796184 \\
\hline 276 & 3 & Consumption & 0.5 & $\mathrm{PD}=7.80 \mathrm{E}-$ & 0.895 & 0.74854580 & 0.82069529 \\
\hline Table II. & 3 & Consumption & 0.9 & $\begin{array}{l}\mathrm{PD}=0.009+2.17 \mathrm{E}- \\
07 \mathrm{GDP}\end{array}$ & 0.884 & 0.76506569 & 0.84641697 \\
\hline
\end{tabular}

data which is an important part in forming the impairment loss allowance model of Indonesian Financial Accounting Standards 71.

Weighted averages are performed on the results of the $\mathrm{PD}$ projection from the integration of the projection of internal patterns and external patterns using the following formula: $\overline{\mathrm{PD}}=w_{1} \overline{\mathrm{P}} \overline{\mathrm{D}}_{\alpha=0.1}+w_{2} \overline{\mathrm{P}} \overline{\mathrm{D}}_{\alpha=0.5}+w_{3} \overline{\mathrm{P}} \overline{\mathrm{D}}_{\alpha=0.9}$. By applying the same weighing to the three smoothing coefficients, the projection $\mathrm{PD}$ values that meet the criteria were obtained, as shown in the following Table VI.

The forward-looking probability of default model of Indonesian Financial Accounting Standards 71 for impairment loss allowance proposed by the authors in this study had proven to be able to represent the prevailing reality. PD values generated from forwardlooking probabilities were close to the real PD value, as proven by the back test. The resulting model was able to produce small errors with high model explanatory capabilities.

The amount of allowance for impairment losses (CKPN) is formed by Bank Jasa Jakarta on the basis of weighted averages of the PD projection, LGD data which uses a combination of a calculation of non-performing loans based on expected recoveries, collateral shortfall, loss on disposal and EAD data which are obtained on the basis of calculations based on gross amount and net Amount. On the basis of the CKPN formed, a gap analysis is then carried out. The gap analysis of the implementation of PSAK 71 against PSAK 55 with respect to the formation of CKPN is shown in Table VII.

Calculation of CKPN with PSAK 71 produces an amount of IDR 18,211,641,822 while the calculation of CKPN with PSAK 55 produces an amount of IDR 16,243,476,789. Therefore, for the implementation of PSAK 71, BJJ has to add the formed reserves to the amount of IDR $1,968,165,033$. The results of the gap analysis based on back test data as of September 2018 show that the impact of the application of PSAK 71 on the formation of CKPN, when compared with the application of PSAK 55, showed a difference of 12.11664879 percent in CKPN. The results of the gap analysis based on data as of September 2018 showed that there was an increase of \pm 12.12 percent, which is an effect of the application of PSAK 71 to the establishment of CKPN compared to the application of PSAK 55. This finding was also in line with the prediction of KPMG (2018) and EY (2018) that implementation of IFRS 9 financial instruments was expected to have a significant impact on the balance sheet, regulatory ratios and capital, as well as accounting systems and processes.

The findings from the application of this model in the calculation of CKPN reinforce previous estimates that the application of PSAK 71 will have an impact on the increase in the amount of allowance for impairment losses (CKPN) formed by banks operating in Indonesia (Beerbaum, 2015; Duh et al., 2012; Lim et al., 2013; Walton, 2004; EY, 2018) because all financial assets will be assessed for at least 12-month ECL and the population of financial assets to which lifetime ECL applies is likely to be larger than the population for which there is objective evidence of impairment in accordance with IAS 39 (Duh et al., 2012; Lim et al., 2013; Walton, 2004). In addition, the estimation of ECL takes into account the time value of 


\begin{tabular}{|c|c|c|c|c|c|c|c|}
\hline Bucket & Segment & $\begin{array}{l}\text { Coefficient } \\
\text { of } \\
\text { smoothing }\end{array}$ & Equation & $\begin{array}{l}\text { Model } \\
\text { reliability }\end{array}$ & $\begin{array}{l}\text { Projection } \\
\text { December } \\
2017\end{array}$ & $\begin{array}{l}\text { Projection } \\
\text { December } \\
2018\end{array}$ & $\begin{array}{l}\text { Innovative } \\
\text { impairment } \\
\text { loss allowance }\end{array}$ \\
\hline 2 & $\begin{array}{l}\text { Working } \\
\text { capital }\end{array}$ & 0.1 & $\begin{array}{l}\mathrm{PD}=-0.12+5.38 \mathrm{E}- \\
08 \mathrm{GDP}-0.32 \text { Inflation }\end{array}$ & 0.969 & 0.05617290 & 0.06554399 & model \\
\hline 2 & $\begin{array}{l}\text { Working } \\
\text { capital }\end{array}$ & 0.5 & $\begin{array}{l}\mathrm{PD}=-1.45 \mathrm{E}- \\
01+7.61 \mathrm{E}-08 \mathrm{GDP}- \\
5.90 \mathrm{E}-01 \text { Inflation }\end{array}$ & 0.908 & 0.10265621 & 0.10494072 & 277 \\
\hline 2 & $\begin{array}{l}\text { Working } \\
\text { capital }\end{array}$ & 0.9 & $\begin{array}{l}\mathrm{PD}=-0.152+7.18 \\
\mathrm{E}-08 \mathrm{GDP}\end{array}$ & 0.858 & 0.09873037 & 0.12570850 & \\
\hline 2 & Investment & 0.1 & $\begin{array}{l}\mathrm{PD}=0.066-0.407 \mathrm{BI} \\
\text { Rate }\end{array}$ & 0.943 & 0.04870250 & 0.05231635 & \\
\hline 2 & Investment & 0.5 & $\begin{array}{l}\mathrm{PD}=-0.022-0.496 \mathrm{BI} \\
\text { Rate }-3.2 \mathrm{E}-01 \\
\text { Inflation }+8.82 \mathrm{E}-06 \\
\text { Kurs }\end{array}$ & 0.894 & 0.06491555 & 0.06156882 & \\
\hline 2 & Investment & 0.9 & $\begin{array}{l}\mathrm{PD}=-0.157+2.11 \\
\mathrm{E}-08 \mathrm{GDP}-0.442 \\
\text { Inflation }+1.24 \mathrm{E}-05 \\
\text { Kurs }\end{array}$ & 0.813 & 0.06831929 & 0.06560542 & \\
\hline 2 & Consumption & 0.1 & $\begin{array}{l}\mathrm{PD}=-0.051+2.08 \\
\mathrm{E}-08 \mathrm{GDP}\end{array}$ & 0.905 & 0.02170936 & 0.02953276 & \\
\hline 2 & Consumption & 0.5 & $\begin{array}{l}\mathrm{PD}=0.079-0.947 \mathrm{BI} \\
\text { Rate }\end{array}$ & 0.922 & 0.03875250 & 0.04716115 & \\
\hline 2 & Consumption & 0.9 & $\begin{array}{l}\mathrm{PD}=0.082-9.69 \mathrm{E}-01 \\
\text { BI Rate }\end{array}$ & 0.920 & 0.04081750 & 0.04942149 & \\
\hline 3 & $\begin{array}{l}\text { Working } \\
\text { capital }\end{array}$ & 0.1 & $\begin{array}{l}\mathrm{PD}=0.934-1.32 \\
\mathrm{E}+00 \text { BI Rate }\end{array}$ & 0.939 & 0.87781500 & 0.88955336 & \\
\hline 3 & $\begin{array}{l}\text { Working } \\
\text { capital }\end{array}$ & 0.5 & $\begin{array}{l}\mathrm{PD}=1.03 \mathrm{E}+00- \\
\text { 1.941 BI Rate }-0.602 \\
\text { Inflation }\end{array}$ & 0.958 & 0.92677530 & 0.92364019 & \\
\hline 3 & $\begin{array}{l}\text { Working } \\
\text { capital }\end{array}$ & 0.9 & $\begin{array}{l}\mathrm{PD}=1.031-1.75 \\
\mathrm{E}+00 \mathrm{BI} \text { Rate }-0.71 \\
\text { Inflation }\end{array}$ & 0.904 & 0.93099400 & 0.92250858 & \\
\hline 3 & Investment & 0.1 & $\begin{array}{l}\mathrm{PD}=1.23 \mathrm{E}- \\
07 \text { Unemployment }\end{array}$ & 0.999 & 0.86525570 & 0.88709712 & \\
\hline 3 & Investment & 0.5 & $\begin{array}{l}\mathrm{PD}=1.20 \mathrm{E}- \\
07 \text { Unemployment }\end{array}$ & 0.997 & 0.84131860 & 0.86255578 & \\
\hline 3 & Investment & 0.9 & $\begin{array}{l}\mathrm{PD}=1.19 \mathrm{E}- \\
07 \text { Unemployment }\end{array}$ & 0.996 & 0.83498231 & 0.85605954 & \\
\hline 3 & Consumption & 0.1 & $\begin{array}{l}\mathrm{PD}=0.487+5.54 \mathrm{E}- \\
08 \mathrm{GDP}\end{array}$ & 0.815 & 0.68027496 & 0.70107100 & \\
\hline 3 & Consumption & 0.5 & $\begin{array}{l}\mathrm{PD}=0.177+1.60 \mathrm{E}- \\
07 \mathrm{GDP}\end{array}$ & 0.821 & 0.73514822 & 0.79520394 & $\begin{array}{r}\text { Macroeconomic } \\
\text { equations lifetime }\end{array}$ \\
\hline 3 & Consumption & 0.9 & $\begin{array}{l}\mathrm{PD}=0.919-3.99 \mathrm{E}+00 \\
\mathrm{BI} \text { Rate }\end{array}$ & 0.819 & 0.74951000 & 0.78492043 & $\begin{array}{r}\text { buckets } 2 \text { and } 3 \\
\text { using TVaR }\end{array}$ \\
\hline
\end{tabular}

money. As a result, the recognition and measurement of impairment is intended to be more forward looking than under IAS 39, and the resulting impairment charge will tend to be more volatile.

The findings of the analysis also show that the formation of CKPN on the basis of the impairment loss allowance model of Indonesian financial accounting standards 71 proposed by the authors is higher than the formation of CKPN on the basis of PSAK 55. Thus, the implementation of lifetime ECL models on PSAK 71 was more prudent than the implementation of incurred loss model in PSAK 55 (Beerbaum, 2015; Johannes et al., 2018). 


\section{JABES 27,3}

\section{8}

Table IV.

Example of the back test results on the working capital segment with smoothing coefficient of 0.1 in the bucket 2

\begin{tabular}{lrrrr}
\hline & Time & PD projection results & PD real & \multicolumn{1}{c}{ Error } \\
\hline Equation & 1 & 0.00630557 & 0.006414 & 0.00010843 \\
PD =-0.12+5.38E-08GDP - 0.32Inflation & 2 & 0.01100624 & 0.011226 & 0.00021976 \\
Reliability of the model = 0.969 & 3 & 0.01898089 & 0.018055 & -0.00092589 \\
& 4 & 0.02736948 & 0.023477 & -0.00389248 \\
& 5 & 0.02332991 & 0.027911 & 0.00458109 \\
& 6 & 0.03432301 & 0.031901 & -0.00242201 \\
& 7 & 0.04261496 & 0.035716 & -0.00689896 \\
& 8 & 0.04220042 & 0.039150 & -0.00305042 \\
& 9 & 0.04205172 & 0.044552 & 0.00250028 \\
& 10 & 0.04707100 & 0.050986 & 0.00391500 \\
& 11 & 0.05651794 & 0.056777 & 0.00025906 \\
& 12 & 0.05617290 & 0.061561 & 0.00538810 \\
& 13 & 0.05896790 & 0.061561 & 0.00259294 \\
& 14 & 0.06145110 & 0.061561 & 0.00010974 \\
& 15 & 0.06364313 & 0.061561 & -0.00208229 \\
& 16 & 0.06554399 & 0.061561 & -0.00398315
\end{tabular}

Figure 2.

The PD projection real PD patterns throughout the observation time

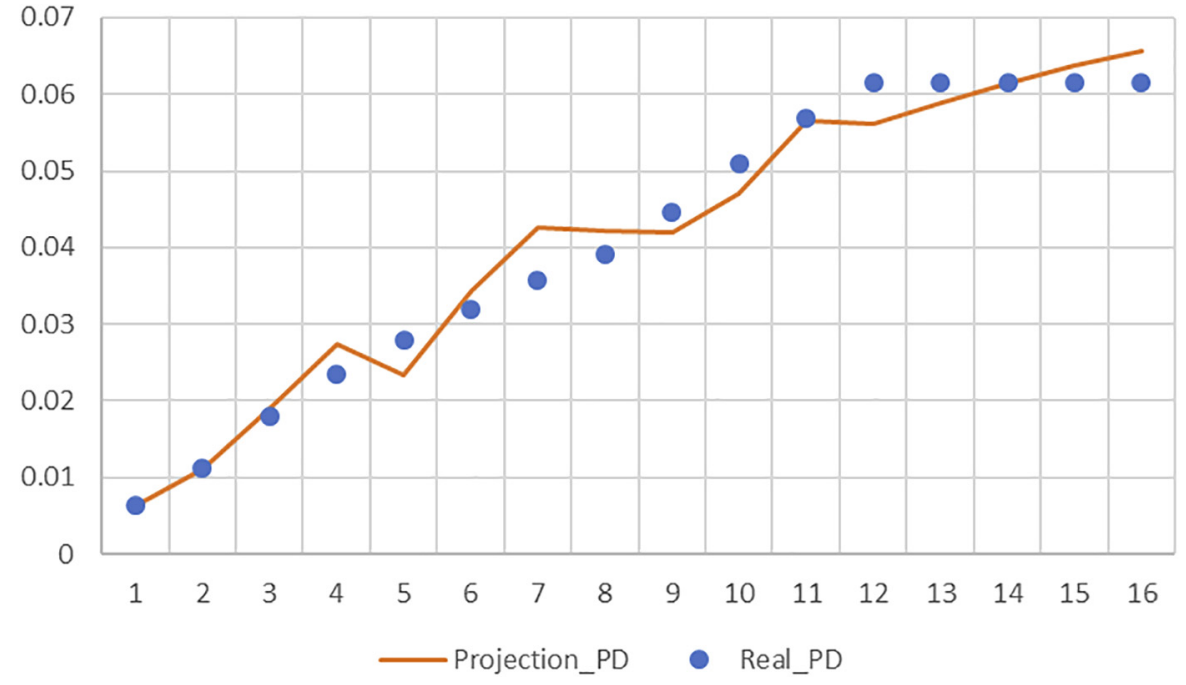

For the authorities, the enforcement of PSAK 71 will be more accountable to the community as the public funds entrusted in the bank become more secure with the increase in reserves of impairment losses formed. The findings of this study are in line with the findings of Johannes et al. (2018) that IFRS 9 will contribute in providing a more objective and prospective view of financial industry.

The results of the gap analysis based on data as of September 2018 show that there is only an increase of \pm 12.12 percent as an effect of the application of PSAK 71 to the establishment of CKPN compared to the application of PSAK 55. This can occur due to several considerations. Historical data on BJJ's non-performing loans in the past ten years shows that the BJJ's gross bank NPL ratio is always in the range of \pm 0.5 percent. The BJJ's NPL ratio is still far below the limit set by the Indonesian banking authorities which sets a 

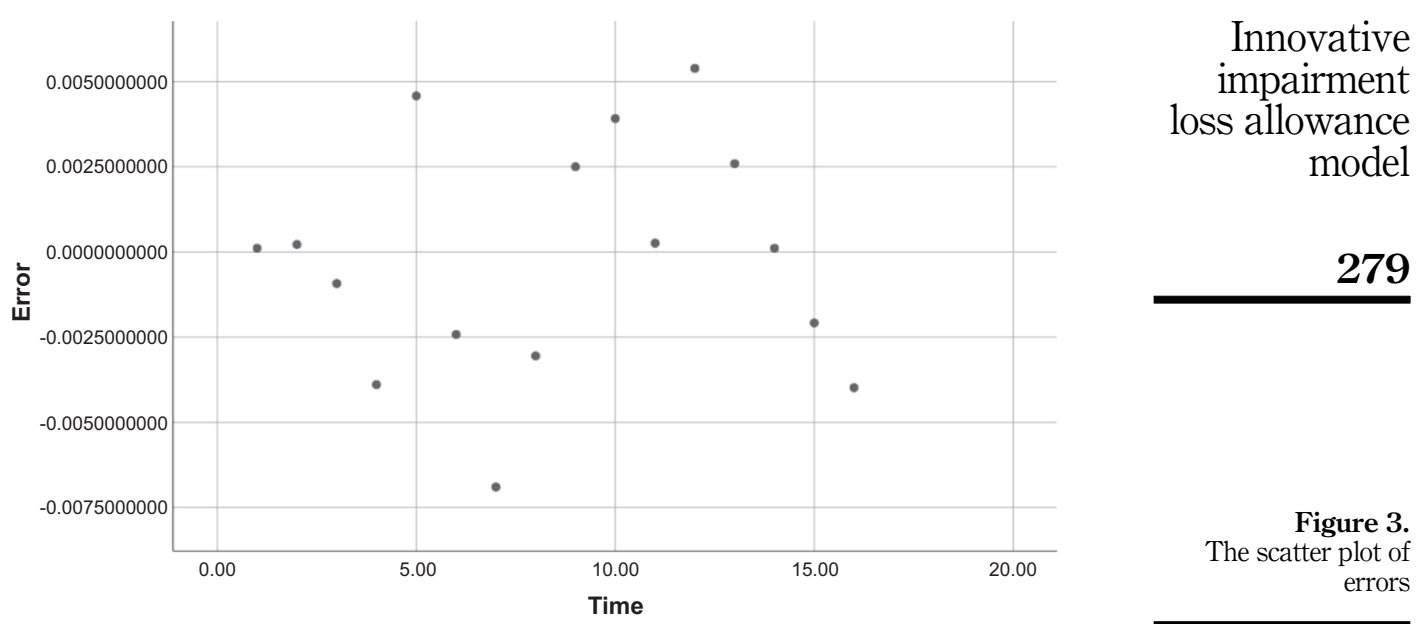

\begin{tabular}{|c|c|c|c|c|c|c|c|}
\hline \multirow[b]{2}{*}{ Bucket } & \multirow[b]{2}{*}{ Segment } & \multicolumn{2}{|c|}{$\begin{array}{c}\text { Coefficient of } \\
\text { smoothing }=0.1\end{array}$} & \multicolumn{2}{|c|}{$\begin{array}{l}\text { Coefficient of } \\
\text { smoothing }=0.5\end{array}$} & \multicolumn{2}{|c|}{$\begin{array}{c}\text { Coefficient of } \\
\text { smoothing }=0.9\end{array}$} \\
\hline & & 2017 & 2018 & 2017 & 2018 & 2017 & 2018 \\
\hline 1 & $\begin{array}{l}\text { Working } \\
\text { capital }\end{array}$ & 0.00053544 & 0.00041759 & 0.00167619 & 0.00185654 & 0.00078155 & 0.00086564 \\
\hline 1 & Investment & 0.00121543 & 0.00134621 & 0.00090104 & 0.00121319 & 0.00027750 & 0.00042845 \\
\hline 1 & Consumption & 0.00085430 & 0.00097617 & 0.00059660 & 0.00076840 & 0.00058371 & 0.00071377 \\
\hline 2 & $\begin{array}{l}\text { Working } \\
\text { capital }\end{array}$ & 0.05617290 & 0.06554399 & 0.10265621 & 0.10494072 & 0.09873037 & 0.12570850 \\
\hline 2 & Investment & 0.04870250 & 0.05231635 & 0.06491555 & 0.06156882 & 0.06831929 & 0.06560542 \\
\hline 2 & Consumption & 0.02170936 & 0.02953276 & 0.03875250 & 0.04716115 & 0.04081750 & 0.04942149 \\
\hline 3 & $\begin{array}{l}\text { Working } \\
\text { capital }\end{array}$ & 0.87781500 & 0.88955336 & 0.92677530 & 0.92364019 & 0.93099400 & 0.92250858 \\
\hline & Investment & 0.86525570 & & & & 0.83498231 & 0.85605954 \\
\hline 3 & Consumption & 0.68027496 & 0.70107100 & 0.73514822 & 0.79520394 & 0.74951000 & 0.78492043 \\
\hline
\end{tabular}

Table V.

The projection $\mathrm{PD}$ formed using three smoothing coefficients

Figure 3.

The scatter plot of errors

\begin{tabular}{|c|c|c|c|c|}
\hline \multirow[b]{2}{*}{ Bucket } & \multirow[b]{2}{*}{ Segment } & \multicolumn{2}{|c|}{ Weighted average } & \\
\hline & & Dec 2017 & Dec 2018 & \\
\hline 1 & Working capital & 0.00099773 & 0.00104659 & \\
\hline 1 & Investment & 0.00079799 & 0.00099595 & \\
\hline 1 & Consumption & 0.00067820 & 0.00081945 & \\
\hline 2 & Working capital & 0.08585316 & 0.09873107 & \\
\hline 2 & Investment & 0.06064578 & 0.05983020 & \\
\hline 2 & Consumption & 0.03375979 & 0.04203846 & \\
\hline 3 & Working capital & 0.91186143 & 0.91190071 & Table VI \\
\hline 3 & Investment & 0.84718553 & 0.86857081 & Weighted averages of \\
\hline 3 & Consumption & 0.72164439 & 0.76039846 & the $\mathrm{PD}$ projection \\
\hline
\end{tabular}


JABES 27,3

280

figure of 5 percent. Thus, the performance of the BJJ's NPL is indeed excellent. Nonperforming loans that occur are dominated by loans that have the type of use of working capital and investment with a relatively short period of time so that the process of impairment mostly uses 12 months. This condition results in the formation of a smaller CKPN. Impact on KPMM (the minimum capital requirement) "does not exist" because in the calculation of core capital, the act of addition / reduction of CKPN expenses that affect the current year's profit is compensated by the calculation of the difference between the allowance for earning assets losses (penyisihan penghapusan aktiva produktif, PPAP) and the CKPN.

The results of this study were corroborated by research findings of Sugiarto et al. (2019) in connection with the quarterly performance ratings of the banks that were members of the BJJ peer group with respect to the NPL variables for the period of December 2015 to June 2018. Even though BJJ's core capital was in 7th rank of the BJJ peer group, BJJ's performance proved to be able to outperform other banks' performance with larger core capital. Throughout the period of observation on BJJ's performance in connection with NPL, this variable improved from 4th place in December 2015 to 2nd place in June 2018. BJJ's NPL performance rating had never been lower than 4 (Sugiarto et al., 2019).

\section{Conclusion}

The findings of the analysis found that it was possible to develop a high-quality and reliable impairment loss allowance model of Indonesian Financial Accounting Standards 71 after verification through real probability of default data back tests and fulfillment of assumptions required in model formation. The resulting model is able to produce small errors, with high model explanatory capabilities. The impairment loss allowance model of Indonesian Financial Accounting Standards 71 proposed by the authors in this study had proven to be able to represent the prevailing reality. By using the model, it can be shown that the implementation of the ECL model on PSAK 71 is more prudent than the implementation of the incurred loss model on PSAK 55. The results of the gap analysis based on BJJ's back data test as of September 2018 indicate a difference of 12.12 percent in CKPN . The findings of the analysis found that implementation of lifetime ECL models on PSAK 71 is more prudent than the implementation of incurred loss model in PSAK 55. For the authorities, the enforcement of PSAK 71 is will be more accountable to the community as the public funds entrusted in the banks become more secure with the increase in reserves of impairment losses formed.

In further research, determination of the bucket to develop a better impairment loss allowance model of Indonesian Financial Accounting Standards 71 can be done more comprehensively by considering the internal credit rating of the debtor. In addition, the scope of research can be extended to touch aspects of hedge accounting in general.

Table VII.

Gap analysis of the implementation of PSAK 71 against PSAK 55 with respect to the formation of CKPN

\begin{tabular}{lrrrr}
\hline & \multicolumn{2}{c}{ PSAK 55 } & \multicolumn{2}{c}{ PSAK 71 } \\
Segment & \multicolumn{1}{c}{ Amount } & \multicolumn{1}{c}{ CKPN } & \multicolumn{1}{c}{ Amount } & \multicolumn{1}{c}{ CKPN } \\
\hline Working capital & $920,822,948,023$ & $9,573,494,431$ & $1,585,334,381,863$ & $9,632,921,586$ \\
Investment & $1,802,772,408,250$ & $3,079,141,979$ & $1,851,767,227,261$ & $5,794,386,274$ \\
Consumption & $984,939,157,265$ & $3,590,840,379$ & $987,000,824,873$ & $2,784,333,962$ \\
Total & $3,708,534,513,538$ & $16,243,476,789$ & $4,424,102,433,997$ & $18,211,641,822$
\end{tabular}




\section{References}

Basel Committee on Banking Supervision (2015), "Guidance on accounting for expected credit losses".

Beerbaum, D. (2015), "Significant increase in credit risk according to ifrs 9: implications for financial institutions", International Journal of Economics and Management Sciences, Vol. 4, p. 287, doi: $10.4172 / 21626359.1000287$

Chambers, J.C., Mullick, S.K. and Smith, D.D. (1971), "How to choose the right forecasting technique", Harvard Business Review, pp. 1-36, available at: https://hbr.org/1971/07/how-to-choose-the-rightforecasting-technique.

Dar, A.A., Anuradha, N. and Qadir, S. (2019). "Estimating probabilities of default of different firms and the statistical tests, Journal of Global Entrepreneurship Research, Vol. 9 No. 1, pp. 1-15.

Deloitte (2018), "Clarity in Financial Reporting", available at: https:/www2.deloitte.com/content/dam/ Deloitte/au/Documents/audit/deloitte-au-audit-applying-expected-credit-loss-model-trade-receivablesusing-provision-matrix-030519.pdf.

Duh, R.R., Hsu, A.W. and Alves, P.A.P. (2012), "The impact of IAS 39 on the risk-relevance of earnings volatility: evidence from foreign banks cross-listed in the USA", Journal of Contemporary Accounting and Economics, Vol. 17 No. 6, pp. 43-55.

EY (2018), "IFRS 9 expected credit loss. Making sense of the transition impact", available at: https:// eyfinancialservicesthoughtgallery.ie/ifrs-9-ecl-making-sense-of-the-transition-impact/ (accessed 15 January 2018).

EY (2019), "IFRS9 expected credit loss. consideration for accounts receivable and contract assets", available at: https:/www.ey.com/Publication/vwLUAssets/ey-ecl-model-of-ar-and-contract-assets-under-ifrsen/\$FILE/ey-ecl-model-of-ar-and-contract-assets-under-ifrs-en.pdf (accessed 22 April 2019).

International Accounting Standard Board (2014), "IFRS 9 financial instruments", available at: https:// www.ifrs.org/issued-standards/list-of-standards/ifrs-9-financial-instruments/.

IFRS Foundation (2014), "Ifrs 9 financial instruments", IFRS 9 Foundation, Vol. 12 No. 6, pp. 21-33.

Ingenbleek, P.T.M. and van der Lans, I.A. ( 2013), "Relating price strategies and price setting practices", European Journal of Marketing, Vol. 47 Nos 1/2, pp. 27-48.

Johannes, R., Dedy, D. and Muksin, A. (2018), "The preparation of banking industry in implementing ifrs 9 financial instruments (a case study of hsbc holdings plc listed on london stock exchange of year 2015-2017)", International Journal of Economics and Financial Issues, Vol. 8 No. 6, pp. 124-136.

Kabir, H. (2005), "Normative accounting theories", SSRN, Vol. 35 No. 6, pp. 31-44.

KPMG (2018), "IFRS 9: transition impact on banks in the UAE and gulf cooperation council" available at: https://home.kpmg/om/en/home/insights/2018/11/ifrs-9-transition-impact-onbanks-in-the-gulf.html.

Ksenofontov, A.S., Savon, I.V., Serba, V.Y. and Shkurkin, D.V. (2016), "Basics of modeling the probability of corporate borrowers' default", International Journal of Economics and Financial Issues, Vol. 6 No. S1, pp. 14-18.

Lim, C.Y., Lim, C.Y. and Lobo, G.J. (2013), "IAS 39 reclassification choice and analyst earnings forecast properties”, Journal of Accounting and Public Policy, Vol. 31 No. 5, pp. 121-134.

Pesaran, M.H., Treutler, B.J., Schuermann, T. and Weiner, S.M. (2005), "Macroeconomics and credit risk: a global perspective", Journal of Money, Credit, and Banking, Wharton Financial Institutions Center Working Paper, pp. 03-13.

PWC (2017), "IFRS 9 for banks", available at: https://www.pwc.com/ee/et/home/majaastaaruanded/ Illustrative_discloser_IFRS_9_for_Banks.pdf.

PWC (2019), "In depth a look at current financial reporting issues, IFRS 9 impairment practical guide: intercompany loans in separate financial statements", April 2019, No. 2018-07, available at: https://www.pwc.com/hu/hu/szolgaltatasok/ifrs/ifrs_9/ifrs9_kiadvanyok/IFRS\% 209\%20Impairment \%20-\%20Intercompany \% 20loans \%20In \%20depthINT(April \%202019).pdf.

Innovative impairment loss allowance model

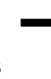


JABES 27,3

PWC (2017a), "IFRS 9, financial instruments. Understanding the basics", available at: https://www. pwc.com/gx/en/audit-services/ifrs/publications/ifrs-9/ifrs-9-understanding-the-basics.pdf.

Rombe, M.L.M. (2018), "The impact of effective forecasting on business growth, a case of business in juba market", International Journal of Economics, Business and Management Research, Vol. 2 No. 1, pp. 196-212.

Sugiarto Nursiana, A. and Budhijono, F. (2019), "Innovation of bank performance index model based on the peer group model of banks operating in Indonesia", Proceedings in 4th GCBME (Global Conference in Business Management \& Entrepreneurship), Bandung, Indonesia.

Surat Edaran, O.J.K. (2017), "S-78/PB.11/2017 perihal penerapan psak 71 (ifrs 9)", available at: https:// www.ojk.go.id/id/kanal/perbankan/Pages/Pedoman-Akuntansi-Perbankan-Indonesia-(PAPI).aspx.

Walton, P. (2004), "Ias 39: where different accounting models collide", Accounting in Europe, Vol. 15 No. 7 , pp. $76-86$.

Watts, R.L. and Zimmerman, J.L. (1978), "Towards a positive theory of the determination of accounting standards", The Accounting Review, Vol. 12 No. 3, pp. 15-26.

Watts, R.L. and Zimmerman, J.L. (1990), "Positive accounting theory: a ten year perspective", The Accounting Review, Vol. 21 No. 5, pp. 54-65.

\section{Further reading}

Aase Nielsen, J. and Sandmann, K. (1995), "Equity-linked life insurance: a model with stochastic interest rates", Insurance: Mathematics and Economics, Vol. 16 No. 3, pp. 225-253.

Akume, D. (2011), "Comparing value-at-risk and tail condition expectation in shortfallconstrained portfolio selection", International Journal of Mathematics and Computation, Vol. 12, article S11.

Boonen, T.J. (2017), "Solvency ii solvency capital requirement for life insurance companies based on expected shortfall”, European Actuarial Journal, Vol. 7 No. 2, pp. 405-434.

Choy, M. and Laik, M.N. (2011), "A Markov chain approach to determine the optimal performance period and bad definition for credit scorecard", Research Journal of Social Science and Management, Vol. 1 No. 6, pp. 227-234.

Chinhamu, K., Huang, C.K., Huang, C.S. and Chikobvu, D. (2015), "Extreme risk, value-at-risk and expected shortfall in the gold market", International Business and Economics Research Journal, Vol. 14 No. 1, pp. 107-122.

Degiannakis, S., Floros, C. and Dent, P. (2013), "Forecasting value-at-risk and expected shortfall using fractionally integrated models of conditional volatility: international evidence", International Review of Financial Analysis, Vol. 27, pp. 21-33.

Fei, F., Fuertes, A.M. and Kalotychou, E. (2012), "Credit rating migration risk and business cycles", Journal of Business Finance and Accounting, Vol. 39, pp. 229-263.

Gavalas, D. and Syriopoulos, T. (2014), "Bank credit risk management and rating migration analysis on the business cycle", International Journal of Financial Studies, Vol. 2, pp. 122-143, doi: 10. 3390/ijfs2010122.

IFRS 9 Snapshot (2013), March 2013, available at: http://www.ifrs.org/current-projects/iasb-projects/ financial-instruments-a-replacement-of-ias-39-financial-instruments-recognitio/impairment/exposuredraft-march-2013/documents/ed-impairment-snapshot-march-2013.pdf.

International Actuarial Association (2016), "Actuarial aspects of erm for insurance companies", available at: http://www.actuaries.org/CTTEES_FINRISKS/Papers/ActuarialAspectsofERMforI nsuranceCompanies_January2016.pdf.

International Financial Reporting Standard 9 (2014), available at: http://eifrs.ifrs.org/eifrs/ bnstandards/en/2014/ifrs9.pdf.

Institute of Indonesia Chartered Accountant (2011), "PSAK 55 - announcement", available at: http:// iaiglobal.or.id/v03/berita-kegiatan/detailarsip-311. 
Institute of Indonesia Chartered Accountants (2017), "Exposure draft - PSAK 71", pp. 1-282, available at: http://iaiglobal.or.draft/ED\%20PSAK\%2071_Instrumen\%20Keuangan_a_Standar.pdf.

Mahayni, A. and Steuten, D. (2013), "Deferred life annuities: on the combined effects of stochastic mortality and interest rates", Review of Managerial Science, Vol. 7 No. 1, pp. 1-28.

Rita Bacinello, A. and Persson, S. (2002), "Design and pricing of equity-linked life insurance under stochastic interest rates", The Journal of Risk Finance, Vol. 3 No. 2, pp. 6-21.

Smart, C.B. (2012), "Here, there be dragons: considering the right tail in risk management", Journal of Cost Analysis and Parametrics, Vol. 5 No. 2, pp. 65-86.

Zaglauer, K. and Bauer, D. (2008), "Risk-neutral valuation of participating life insurance contracts in a stochastic interest rate environment", Insurance: Mathematics and Economics, Vol. 43 No. 1, pp. $29-40$.

Ziegel, J.F., Krüger, F., Jordan, A. and Fasciati, F. (2019), "Robust forecast evaluation of expected shortfall”, Journal of Financial Econometrics, Vol. 18 No. 1, pp. 95-120.

\section{Corresponding author}

Sugiarto Sugiarto can be contacted at: sugiarto.sugiarto@pmbs.ac.id
Innovative impairment loss allowance model 